\title{
Music and Virtuosity: a Higher Vision for Business
}

\author{
Kevin Jackson $^{1,2}$
}

Received: 1 October 2016 / Accepted: 17 February 2017 /Published online: 27 February 2017

(C) Springer International Publishing 2017

\begin{abstract}
Business and music, when at their best, embody virtuosity. This article presents the concept of virtuosity in music as an analogue for deepening understanding of, and for cultivating, virtuosity in business. Among the advantages of undertaking the comparison is the assistance it provides in envisioning business in a new light, a task especially called for in a climate of disillusionment with economic institutions and economic actors.
\end{abstract}

Keywords Musical virtuosity $\cdot$ Business performance $\cdot$ Reputation $\cdot$ Virtue $\cdot$ Cultural capital

\section{Introduction}

Business and music, when at their best, embody virtuosity. This article presents the concept of virtuosity in music as an analogue for deepening understanding of, and for cultivating, virtuosity in business. Accordingly, a metaphor of virtuosity as a higher vision for business will be portrayed around the following quartet of images.

\section{Visualizing the Market Participant as Virtuoso Artist}

The businessperson's or business firm's competitive performance, like that of a musician, is driven by creativity, authenticity, self-knowledge, inner discipline, and the pursuit of excellence. Such characteristics cannot be prescribed by rules or regulations, nor can they be effectively instilled by threats of sanctions for noncompliance, but instead require an engagement with higher and more noble ideals springing from our nature as humans in search of fulfillment.

Kevin Jackson

kjackson@fordham.edu

1 Gabelli School of Business, Fordham University, 45 Columbus Avenue, 5th Floor, New York, NY 10023, USA

2 Université Libre de Bruxelles (ULB), Brussels, Belgium 


\section{Comprehending Business as Existential Human Endeavor}

We cannot understand business unless we understand the human condition, since that is the wellspring from which all relationships of commerce and trade ultimately flow. One must confront fundamental questions of free choice, reason, and authenticity of character. In today's globalized world, where the corporation often arrogantly asserts its metaphysical stature as a distinctive "person," seeking to earn (if not outright command) our trust, even while frequently violating it, we ought to have some notion of just what such an extension of trust might mean, what the stakes are, and whether we are prepared to abdicate our own human moral responsibility while ceding authority to corporations in the pursuit of ever greater technological and material conquests, as individuals and as a society.

\section{Juxtaposing Cultural and Reputational Capital alongside of Financial Capital}

Intangible assets such as character, honor, and virtue are preconditions of business success, yet at the same time they have intrinsic worth which, paradoxically, must be honored to trigger that success. The way that culture promotes (or fails to promote) such intangible assets profoundly influences whether business flourishes or decays. Conversely, the way business promotes (or fails to promote) these intangible assets will profoundly influence whether our culture will flourish or decay.

\section{Adopting a Sapiential Outlook on Business Embracing Virtue and Objective Morality}

As virtue theory asserts itself in business ethics it is important to honor ancient wisdom about the primacy of virtue, seeking at the same time to rekindle the passion for pursuing it and for engaging it in fresh approaches to contemporary economic ethics.

From the standpoint of virtuosity, the aim is to inspire business, encouraging reflection on it might look like were it conducted with the exacting self-imposed standards of excellence that inspire musical artistry. The challenge is setting out a narrative for business and economic life coming from a higher, more noble vantage point than self-referential discussion of business about itself often allows.

\section{Virtuous Performance and Reputational Capital}

Consider what happens when a virtuoso artist fails to deliver the exemplary performance his audience anticipates. This unfortunate occurrence unfolded when tenor Robert Alagna gave a performance of Aida at Milan's La Scala that set off hisses and jeers from an audience that deemed his singing of the opening aria to fall short of their notoriously high standards of excellence (Wakin 2006). Usually, a sub-par performance causes a musical artist to suffer a temporary loss of honor and reputation. Sometimes it can deliver a death-blow to a career.

Now consider the situation when a business leader or firm falls short of an anticipated level of virtuosic performance. In the wake of his handling of executive compensation practices, in light of questions raised about whether his firm properly disclosed 
information to both sides of trades on complex financial instruments (CDOs) that bundled mortgages, and in regard to suspicion about having assisted Greece in masking the extent of its debts, Lloyd Blankfein, formerly an esteemed chairman and CEO of Goldman Sachs, was branded one of the "Most Outrageous CEOs" by Forbes magazine, and shortly thereafter his venerable firm was excoriated by the U.S. Financial Crisis Inquiry Commission (Coster 2009).

Inviting this comparison of music and business trades on two distinct senses of "virtuous" performance. Critics will point out the differences between inspired musical performance and enlightened business performance. For instance, the moral dimension, which this article seeks to showcase in offering a conception of the virtuous businessperson and firm, does not normally figure directly or prominently into one's assessment of a musician's virtuoso status. However, it is interesting to note the case of Joyce Hatto, a concert pianist who, either on her own or with her husband's complicity, fraudulently produced over one hundred recordings of other pianists' renditions, passing them off as her own recordings. In such a case, the moral dimension figures into assessment of the counterfeit virtuosity. Ironically, she was reputed to be a good, if not extraordinary pianist on her own merits (Bintliff 2007).

Clearly there are differences between the respective purposes of music and business, different types of harm resulting from failure in each, not to mention the different ontological make-up of individual artists and business entities.

At any rate, the differences are not as significant as may first appear, and one can learn a good deal by looking past them to fix one's gaze on the intriguing ways in which the two cases are analogous. For instance, in both music and business there is a vital dependence on selfregulation and self-imposed standards of excellence. In both, mere "compliance" with rules is but the barest of minimal conditions. Alagna was not being faulted for any mere technical lapse in execution of "Celeste Aida." Nor were Blankfein and Goldman Sachs being cited, in regard to the moral dimension, for technical noncompliance with crisp legal directives. The moral critique of their performance delved deeper into matters of probity and character not readily captured in any bill of do's and don't's (Clark 2010). This article seeks to highlight such similarities to point to a higher path for business. That path is formed by the standards and state of the soul of the virtuoso.

Virtuosity in musical performance is about artistry. Although the cultivation of artistry demands consistent practice and fastidious attention to detail, artistry is not simply a matter of technical mastery of an instrument and execution of the right notes (though these are obviously important). Similarly, the virtuoso businessperson or company does not attain excellence, nor does it build the reputational capital that attends it, (Jackson 2004) through any mechanical or technical achievement alone.

\section{A Conceptual Framework for Music and Business}

Remaining mindful of the obvious differences between music and business, let us turn to some concepts that will help draw out salient features the two callings share. The aim is to arrive at a fresh understanding of significant yet otherwise unnoticed moral characteristics of business through an examination of fundamental aspects of music. Many of these aspects figure prominently into other creative human endeavors too, such as sculpture, architecture, painting, and other fine arts. 


\section{Praxis, artis, Reinforcing Institutions, Goods, and Virtue}

The concept of praxis, together with associated notions of artes (virtue-rich practices), reinforcing institutions, internal and external goods, and the vitalizing role that virtue performs within them, will assist in establishing a plausible congruence between musical virtuosity and its counterparts in the life of business.

By praxis is meant the customary, creative, cooperative process through which an artis that is, some theory, art, lesson or skill - becomes enacted, embodied or realized. Within this process, various goods (which may be tangible or intangible) that are internal to the particular kind of practice at hand are brought to fruition as a result of efforts to attain levels of excellence both tied to and partly constitutive of such an endeavor.

In this account of praxis a cluster of five elements may be distinguished: (i) praxis involves social and co-operative human activities; (ii) the creative human process is engaged; (iii) the outcome of engagement in praxis is the achievement of internal goods appropriate to the particular artis, understood as goods identified with both the excellence of the products that result from the praxis (such as the excellence of a musical composition and the excellence of the musicians' performance of it), as well as the perfection of participants in the process of their production; (iv) the relevant standards of excellence for the artis have been established historically by some community of practitioners; (v) activities undertaken through praxis get transmitted and reshaped through traditions comprising successive rounds of internal debate about, among other things, their own standards of excellence.

Our participation in praxis can be complex. It may be simultaneously determinate yet indeterminate the way that a Beethoven piano sonata is: the composition is fixed by notes and markings in the score, yet amenable to being rendered in innumerable ways by its performers' variant interpretations of it. Likewise, a franchise business may embody a high level of determinacy (McDonald's restaurants are uniformly designated to have their French-fry cookers in the same location); even so, countless features are open to the discretion of the franchisee running an individual outfit. Moreover, involvement in praxis may be selfinterested but at the same time community situated. It is not simply an object for detached investigation, nor is it merely a set of institutions. For both music and business, their lifeblood involves relationships based on the human practice of exchange, even though the substance of what is exchanged is much different in these respective endeavors. Nevertheless, both music and business involve an ongoing process of meaning and value creation. The wealthpromoting exchanges of business and the enrichment-giving exchanges of music are sustainable to the extent that they activate the dynamic process of creativity and are embedded within multivalued communities.

Furthermore, praxis involves fundamental tensions between efficiency and creativity which require artistry to balance successfully. Thus, on one side, efficiency is rooted in habit, convention and continuity. Efficiency is reactive and based on the status quo; it involves a determinate process of calculation identifiable within a relatively static and closed environment. By contrast, creativity flows out of an environment of potentiality, discontinuity and indeterminacy. Creativity involves a dynamic process of discovery and invention. It is proactive and continually evolving.

The phenomenon of praxis is all-pervading. We spend much of our lives in praxis-based activities, since they range from involvement in the arts and sciences to participation in sports and games, from the practice of politics in the broad Aristotelian sense to the maintenance and enjoyment of family life. Virtue plays a vital role across all of these undertakings since the 
deployment of virtue is the sine qua non for the achievement of the goods internal to such artes or virtue-laden creative practices.

Goods internal to praxis, however, are not the only kind of goods. One may contrast them with goods external to particular practices such as survival, power, profit, reputation and success. External goods are often the objects of competition in which there are both winners and losers. With internal goods, however, although there is competition in one sense, this is competition to excel. As such, this kind of competition serves to benefit not just the "winners" but all the members of the community engaged in the practice, as is seen in the way that participation in music competitions improves the performance ability of all the contestants. ${ }^{1}$

For internal goods to be realized, the traditions and practices out of which they arise need to flourish. Usually, to accomplish this, reinforcing institutions involved with external goods play a crucial role. As Alasdair MacIntyre notes, such supporting institutions typically deal with the acquisition of money and a range of material goods. Reinforcing institutions are configured by means of norms that establish authority, and also by prestige, and such institutions allocate wealth, power and status as recompense (MacIntyre 1984, 194). As well, such sustaining institutions play a key role as social transmitters of praxis-based activities.

Numerous examples of reinforcing institutions contributing to musical flourishing come to mind: orchestras, bands and ensembles; teaching studios, music schools and conservatories; churches and other houses of worship; agents, managers and producers for concerts, recitals, gigs and recordings; competitions, festivals; publishing houses and other media for visual and audio dissemination; instrument manufacturers and craftspeople, and so on.

This account of reinforcing institutions and their relationship with praxis can be applied to many diverse contexts, including not only music but productive arts, broadly construed, as well. One may regard the business organization as a peculiar sort of hybrid made up of, on the one hand, praxis and, on the other hand, a form of reinforcing institution affiliated with the praxis. A given artis might be blacksmithing, computer programming, soybean production, or graphic design, or it might involve producing pharmaceuticals, delivering on-line retailing, or providing financial services. What these artes have in common is that such practices fall within the scope of the aforementioned idea of praxis, and that in order to be sustained the artes are typically institutionalized, to a greater or lesser extent.

We can turn our reflections to business in an effort to identify various features of a virtuous organization, inquiring as what kinds of leadership responsibilities might ensure that these features exist and are fostered. The first requirement of a virtuous organization, in accordance with an Aristotelian orientation, would be that there is a good purpose for the particular artisinstitution fusion that it represents. Second, the institution would be aware that it is founded on and has as its most important function the sustenance of the particular practice that it houses and following from this the organization would encourage the pursuit of excellence in that endeavor whatever that may mean for the particular practice in question. Third, the institution would focus on external goods (such as survival, power, profit, reputation or success) as both a

\footnotetext{
${ }^{1}$ Cf. Alasdair MacIntyre's concept of a "practice," which he defines in the context of a more general discussion of the role of the virtues in moral life as follows:

"any coherent and complex form of socially established cooperative human activity through which goods internal to that form of activity are realized in the course of trying to achieve those standards of excellence which are appropriate to, and partially definitive of, that form of activity, with the result that human powers to achieve excellence, and human conceptions of the ends and goods involved, are systematically extended" (MacIntyre 1984, 187).
} 
necessary and worthwhile function of the organization, but only to the extent necessary to the sustenance and development of the practice. Finding the right balance between internal and external goods stands as an essential challenge for business organizations.

\section{The Challenge of Integrity}

There are two significant factors influencing the ability of a practice to cultivate and maintain its internal integrity. The first factor can be termed lex artis (law of the art or skill), meaning respect for the spirit and letter of rules and principles that help to guide the practice qua professional activity. The second factor concerns virtuosity - the way in which virtue can be and is exercised in sustaining the institutional forms which are the social transmitters of the artis. Accordingly, on the one hand, the integrity of an artis flows from an appropriate regard for lex artis, the relevant norms that make it hang together, along with the exercise of virtue by at least some of the participants who embody it in their activities. On the other hand, the corruption of institutions - as witnessed in corporate scandals and across the financial crisis - is typically attributable at least in part to violations of norms along with the proliferation of vice.

As such an analysis would lead one to expect, a failure to possess and exercise virtue along with a disregard for lex artis, ultimately leads to the inability of practices, whatever variety they may be, to retain their integrity - and hence, to the demise of associated institutions which cease to foster the practice upon which they are based. Such an integrity-collapsing dynamic occurred with the financial crisis. The crisis cannot plausibly be attributed solely to any lack of technical knowledge, but rather from inattention to, among other things, moral standards, themselves in a state of disarray from a myriad of social and philosophical dysfunctions from the wider culture (Jackson 2010).

We can build further upon the music analogy. Horowitz's great artistic achievement came not simply from technical prowess, though his was enormous, but from the overall integrity he championed: his matchless taste and inclination for making correct judgment, his great reservoirs of passion and creative vision. And in those rare occasions when he delivered a wrong note from the concert stage, it was understood by all but pianistic dullards or pedantic critics that such a technical blunder was a mere trifle, the unavoidable consequence of Horowitz pushing the envelope in the quest for the highest possible interpretation he was inspired to concoct.

Whether people are seated around the table of a corporate boardroom making decisions that carry moral import, or whether they are seated as players in a chamber orchestra, the center of gravity of their shared endeavor is excellence, the pursuit of the very best they can be as individuals and as a group, seeking a state of happiness, for themselves, and for those whose lives are touched by their art, in the deep sense expressed by ancient minds. Doing something well is profoundly more important than simply doing something.

During the past two decades, the moral volatility of business has become manifest in striking ways. The global financial crisis has shown that virtuosity cannot be underrated regardless of how intricate the financial formulas may become. It would not be fair to say that the prior collapses of the dot.com firms, Enron, Aldelphia, Parmalat, Tyco International, Arthur Andersen and WorldCom were occasioned entirely by ruthless and evil individuals, but rather by financially savvy and technically adroit people who lost track of moral values in their pursuit of narrow economic objectives. Devoid of any robust appreciation for the moral and cultural significance of what they are accomplishing in their enterprises, there is a persistent danger that businesspeople may misapprehend the impact that their pursuits have on the 
broader culture. In due course they become detached from their own souls and the souls of their companies.

\section{Virtue, Profit, and Culture}

If one considers virtues as business assets, are there situations where greater profitability comes from making a pretense of virtue rather than the authentic cultivation and exercise of it? As Groucho Marx quipped: "The secret of life is honesty and plain-dealing; if you can fake that, you've got it made." In fact, the inclination of market participants to imitate moral virtues such as honesty and generosity bespeaks the presumed competitive advantage that flows from acting virtuously.

It is urgent to enter into a philosophically rigorous conversation regarding what is meant by being "good" and "successful" in business, and to clarify the virtues required for being a good businessperson. By entering into such a conversation, one starts to discern specific illustrations of the good businessperson and the good business enterprise. At the same time, one begins to acquire a deeper and more comprehensive and accurate knowledge of what it means to generate wealth than is provided in mainstream economic literature.

The conversation is aided by reflection on the significance of cultural capital, conceived of as an intangible moral resource necessary to develop the virtues for achieving excellence in business, whatever one's station. The virtuoso businessperson is not only a self-project of individual motivation and effort, but the cultivation of her virtuosity ultimately depends upon the culture - its institutions of family, education, and the arts - to provide the formation that fosters excellence.

\section{Profit and the Virtuoso Business}

It is posited that a virtuoso company is a far cry from the stereotypical "profit machine." Even though it seeks to generate profit, the virtuoso company looks at profit along the lines that we view the air we breathe: of course everyone knows that we need it, but it's not the end-all-andbe-all of life. Writing about visionary companies, Collins and Porras state that

Profitability is a necessary condition for existence and a means to more important ends, but it is not the end in itself for many of the visionary companies. Profit is like oxygen, food, water, and blood for the body; they are not the point of life, but without them, there is no life (Collins and Porras 1994).

Such companies embrace a "core ideology," or "vital shaping force" which might stem from its origins, as in the case of Sony; or, as with Merck, from a successive generation; or even remain quiescent to be revivified at some subsequent point, as occurred with Ford (Id. 54). A virtuoso firm might have as its principal motivations professionalism, civic responsibility and customer service, like Housing Development Finance Corporation (Paine et al. 2001). Its driving force could be "bedrock values" of personal accountability, respect for the individual, truth, and fair dealing, like Sealed Air Corporation (Paine and Wruck 2005). Or it may be spurred on by a commitment to integrity, fairness, fun, and social responsibility, as AES Corporation is (Paine and Mavrinac 2009).

There is an important connection between the existentialist idea of individual human authenticity (Sartre 1992/1943) and what may be termed a "corporate existentialist" idea related 
to a firm's commitment to a core moral or social project. As with a human being, the organization must have an authentic commitment to its objectives, in a way that is true to its own character and internal nature as a moral agent that is free to choose. It cannot simply mimic the values of other firms, conform to external diktats, or smartly calculate which roster of values will likely prove to be the most lucrative, trendy or well-liked (Collins and Porras 1994, 75).

No matter how a company articulates its mission, profit maximization normally is not brazenly listed as its primary objective. In reality, profit is a predictable and reliable side-effect that arises in an indirect fashion from a company seeking other aspirations. Support for this thought is found in Collins and Porass' extensive study of companies noted for attaining exceptional long-term performance. Among their findings, the authors note a shattering of the myth that the companies achieving the highest degree of success owe their existence principally to the quest for profit maximization:

Contrary to mainstream business school doctrine, "maximizing shareholder wealth" or "profit maximization" has not been the dominant driving force or primary objective through the history of the visionary companies. Visionary companies pursue a cluster of objectives, of which making money is only one - and not necessarily the primary one. Yes, they seek profits, but they're equally guided by a core ideology - core values and sense of purpose beyond just making money. Yet, paradoxically, the visionary companies make more money than the more purely profit-driven comparison companies (Collins and Porras 1994, 8).

The idea here is clear-headed and insightful: narrowing in on profit alone makes an enterprise lose sight of its authentic mission. Conversely, if a firm remains guided by its true objective, then profit is naturally produced in due course. An analogy to music will underscore and clarify the point. For a pianist who practices a difficult passage of a piece slowly and carefully, velocity will eventually come as an organic outcome of the performer's diligence, a natural result of the fingers having gained confidence in their movement from note to note. Attempting to play the passage too soon at top speed will prove counterproductive. In the same way, for the firm that narrowly pursues profit directly, in too hastily a fashion without regard for care in gaining the assurance of customers and other constituents that it is accomplishing its purpose, the effort is bound to backfire.

Collins and Porras demonstrate in their work how companies that elevate profit to the apex of their business plan, considering everything else as subordinate to it and deeming this to be the principal means by which to beat the competition, quickly forfeit whatever competitive advantage they may have been pursuing. Rather than "beating the competition," visionary companies,

focus primarily on beating themselves. Success and beating competitors comes to the visionary companies not so much as the end goal, but as a residual result of relentlessly asking the question "How can we improve ourselves to do better tomorrow than we did today?" And they have asked this question day in and day out - as a disciplined way of life - in some cases for over 150 years. No matter how much they achieve - no matter how far in front of their competitors they pull - they never think they've done "good enough" (Collins and Porras 1994, 54).

Collins and Porras, drawing a comparison between visionary companies, such as HewlettPackard and purely profit-driving companies such as Texas Instruments, quote the words of James Young, former CEO of Hewlett-Packard: 
Maximizing shareholder wealth has always been way down the list. Yes, profit is a cornerstone of what we do - it is a measure of our contribution and a means of selffinanced growth - but it has never been the point in and of itself. The point, in fact, is to win, and winning is judged in the eyes of the customer and by doing something you can be proud of. There is symmetry of logic in this. If we provide real satisfaction to real customers - we will be profitable (Collins and Porras 1994, 57).

These observations about loosening the grip on profit-maximization squares with the dynamic of detachment espoused by spiritual traditions from antiquity. As Deepak Chopra expresses it:

the Law of Detachment says that in order to acquire anything in the physical universe, you have to relinquish your attachment to it. This doesn't mean you give up the intention to create your desire. You don't give up the intention, and you don't give up the desire. You give up your attachment to the result (Chopra 1994, 83).

These reflections help to illuminate the moral foundations of the free market, as well as the kind of resources upon which it depends. Yet they draw our attention to an important intangible asset that is largely neglected by mainstream economics: that asset is cultural capital.

\section{Cultural Capital}

The concept of cultural capital refers to the reservoir of lively interrelations among people, along with mutual concern, shared understandings, common moral values, and trust. This intangible social asset solidifies affiliates of human communities and associations. It enables cooperative pursuits to materialize. Cultural capital lifts organizations and business communities higher, making them more than just a haphazard group of people each bent on advancing their respective private projects. The idea signifies the wherewithal required in running everyday dealings in public life. Those resources comprise moeurs, beliefs, customs, habits, and morals - that is, the multifarious traditions we learn from our parents that render us suitable participants in the social and economic order.

Forming the core of this article's approach is a devotion to moral virtues developed within a culture which have the ability to ripen the excellence of the whole person. Considered by themselves, neither the market nor the government can accomplish this. The virtuosity approach acknowledges that technical business competence and informed government policies, while imperative, cannot of themselves assemble a good company or a good businessperson. The virtuosity approach, comprehended within a broader philosophical tradition that recognizes an objective moral order understands that the wellsprings of goodness mainly flow out of culture and the institutions it inspires, not from markets or governments. Absent a morally-fortified culture, the state inclines towards totalitarianism, while the market leans toward rampant careerism and crass consumerism. These points hearken back to the ancient wisdom which counsels that "without vision, the people perish" (Proverbs 29:18).

The free market is the engine of economic advancement. To be sure, government is required to lay down rudimentary rules of the road. However, at the end of the day it is culture that formulates the point, the mission, and the final destination of the voyage.

Given the importance of culture, it would be a good idea to clarify what is meant by the term. As its root suggests, culture serves to inculcate a way of viewing the world, to perceive what is real, to bring sense to reality. Culture generates a feeling for what matters, what is 
deserving of sacrifice. Culture illuminates what we hold as sacred, guiding us to apprehend the deepest meaning extending back to our beginnings and ahead to the future. With the help of culture we can sift through data, opinions, and choices, and arrive at what matters.

Human society rests upon a foundation of cultural institutions. Family and education ${ }^{2}$ are two of the foremost institutions vital for economic society. The central importance of family can be appreciated when we acknowledge that it comprises the primary component of human culture; family is the basic unit of society. ${ }^{3}$ As for education, it cultivates and awareness of and sensitivity toward the world, inspiring a sense of wonder (for Aristotle, the origin of all knowledge), firing the imagination, and granting the moral vision necessary to enlighten scientific, technical and commercial undertakings.

Philosophy, understood in its wide sapiential sense, along with religion, the arts, music, literature and other humanities are at the center of culture. These endeavors are concerned with what is most precious and noble in our lives. These wellsprings of higher culture prompt us to engage the deeper significance of our world by pointing beyond the drab concerns of everyday things to what is more enduring, by directing us toward ultimate questions concerning our nature, our purpose and our destiny. To be sure, there are also influences from mass culture such as television, the internet, sports and games. Yet compared to philosophical, religious and artistic sources of inspiration, mass culture does not provide a rich enough soil for human flourishing to occur.

The reason for this stems from a dynamic that has been understood from antiquity: by drawing us back to our purpose, to our authentic nature, to our destiny, the higher forms of culture equip us to perceive the whole, not simply the fragments. Culture equips us to assimilate the totality of the cosmos and guides us to comprehend how we fit into it. We grasp the wholeness by being united with elemental cycles of our existence such as living, growing, dying, loving, and working so as to relate them in an organic unity instead of in a subdivided way. Hidden at the center of all cultures deserving of the name is a yen to reunite what is detached.

In concrete terms, culture establishes a shared way of life that is informed by moral norms and values. Having its roots in tradition, it is infused in education, family, the arts and humanities, providing a way for us to grasp reality as a meaningful whole. These cultural institutions help to implant in us a love of virtue, and to point us toward the purpose for which we were made, the good life.

When considering the influence that cultural institutions wield on business, it is critical to be specific and concrete as opposed to exclusively universal and abstract. The reason is that cultural institutions derive their vitality from particular features of the communities out of which they grow. Instead of confronting head-on the skirmishes between cultural differences, many people are inclined to retreat up into the high country of highly abstract values that are sanitized of any specific cultural or religious reference.

Such an approach typifies many theoretical approaches to business ethics, which attempt to lend moral guidance by assuming a "view from nowhere."

\footnotetext{
${ }^{2}$ Here 'education' is used in a broad sense, encompassing not only what is taught in schools but also in churches, temples, synagogues, and mosques, and other associations.

${ }^{3}$ A recognition of the vital importance of the family institution is expressed in the following passage:

It is surprising to see that humanity's oldest institution, the one making it possible for people to live a harmonious and balanced life, and the very origin or society, is the target of ideological attacks. The family, not the individual is the basis of society, since the latter can't fully develop itself on its own: it's not self-sufficient and is naturally family orientated (Chinchilla and Moragas 2008, 120).
} 
Certainly, it is important to accommodate some measure of cultural relativity. Nevertheless it is equally crucial to bear in mind a fundamental insight. One becomes the best one can be when animated from the core of one's being rather than from the margins of one's being. To the extent that one veers away from the core in daily life, one will be compromising one's potential for excellence.

When we consider the landscape of cultural pluralism across the globe, it is tempting to think that the preferred way, or perhaps even the only way to conduct public discourse is to proceed from the standpoint of the least sophisticated level, that is, on the basis of that which is accepted by the widest mass of people rather than what is most rational. Certainly it is necessary to listen to a variety of viewpoints. Yet this mode of discourse seldom lets people get in touch with their innermost convictions and develop the virtues that are required to realize those convictions. The gulf that separates work and virtuosity engenders a kind of nihilism throughout much of today's business world - crossing all peoples and cultures. People toil away for the bulk of their lives in soulless organizations which drive on as if respect for persons does not matter, as if nothing in the tasks they undertake pertains to the pursuit of the good life and to timeless human values.

What is needed is a way of connecting one's vocation in business to an ethical outlook on commercial life. This would involve linking:

- business life to a community of virtue;

- generation of goods and services to the end of human flourishing;

- allocation of wealth to the merits and needs contributing stakeholders;

- private profit, private ownership, private risk, private initiative to the common good;

- employment to the cultivation of excellence and pursuit of well-being in employees.

At its zenith, culture engenders a commercial order that civilizes the business world so as to promote the growth of virtuous enterprises, which in turn advances the common good.

We must not turn away from the promise of building authentic cultural capital in business in the name of the postmodern retreat from objective values and out of some absolute worship for diversity, pluralism and tolerance. Placing an emphasis on virtue and the objective moral order supplies the mindset and the vocabulary with which to approach this challenge.

Straightforward conversation about the ways that cultural capital inspires and develops virtuous businesspeople can stimulate meaningful discourse across cultures. This, in turn, may engender harmony among them. Such a heightened degree of rapprochement between morality and business may promote more profound interactions among cultures around the world that will equip them to negotiate whatever thorny ideological divergences exist. Yet it is not plausible to believe that we impart moral wisdom to one another if we simply follow government laws and regulations or mimic technical financial methodologies. In truth, the profit-driven mindset, collective laws and conventional practices, and the econometric worldview are all too constraining for the art of business to flourish.

The notion of cultural capital provides a means of explanation for why the so-called profit motive is best interpreted as something broader than a relentless quest for profit maximization. Most of what is needed to create profit is attainable only through the cultivation and deployment of cultural capital. And although this type of intangible capital is not amenable to being reduced to a specific item on the balance sheet, nevertheless it contains value as a path to enhancing the bottom line. 
Therefore, the idea of cultural capital should be brought within the orbit of economic thinking. A business can invest in cultural capital in much the same way that it can invest in reputational capital, human capital, or other types of capital. Likewise, a business can draw upon cultural capital just as it can draw upon these other forms. Yet accomplishing this involves adopting a non-traditional style of management, one which is as vital in business as in day-to-day living, even though it has tended to elude economic understanding: the sapiential management of intrinsically valuable human goods. Keeping in mind a good result that might flow from pursuing one's aim, while not making that the goal itself is something of an art. To analogize, the concert pianist who has attained great success in her career - sold-out concerts wherever she tours - has done so not by devoting her attention directly and exclusively to that goal, but rather by focusing her intentions on other goals: playing her instrument well, building a solid repertoire, maintaining disciplined practice, being the best she can be with the talent she was given. When all of those things are in place, her recognition and the success that accompanies it follow as natural byproducts.

We see this dynamic at work in the motivation for virtuous conduct as well. The virtue of courage can help bring about good results. When one has courage, one is poised to go after what one wants. However, as a courageous person, getting what one wants is not the main motivation. After all, a cowardly person is also motivated to get what he wants. What sets the courageous person, apart from the coward is that the former views her behavior as an external observer would survey it. Adam Smith refers to this as the point of view of the impartial spectator. One carries a sense of pride by acting courageously. One believes that one's sense of responsibility and a due regard for one's reputation and honor warrant assuming a risk. As a result of viewing one's behavior in this way, as seeing that it is the morally correct action to take, independent of the concern for simply getting what one wants, a person gains recompense.

The inability, or persistent unwillingness, to apprehend this dynamic leads to profound misunderstanding and confusion concerning the profit motive. The assumption underlying mainstream economics is that a business seeks to turn a profit; within the market system, the profit-seeking efforts of many enterprises synchronize their behavior to attain a balance. However, in declining to scrutinize real motivations of human beings making up the businesses, the neo-classical synthesis fails to supply any adequate account of the manner in which the profit motive actually arises within people. Accordingly, for some, it appears as if the entire economic order is based upon the pursuit of cold-blooded selfishness.

Adam Smith delivers a much different interpretation in The Theory of Moral Sentiments (Smith 1759). Competition within a free market competition is accompanied by a multitude of moral concerns, among them benevolence, sympathy, and the stance of the impartial spectator (the counterpart of which may be found throughout the legal tradition as the "reasonable person"). All of these characteristics flow directly from the wellsprings of human nature. Thus moral considerations temper the otherwise ruthless pursuit of profit. What appears from one standpoint to be a savage quest for self gain might be, from an alternative interpretive standpoint, a manifestation of benevolence. Human motivations are typically multidimensional and highly nuanced. Sometimes the best means of attaining an objective is by disregarding it, rather than attempting to go straight to it. (That is what Bertrand Russell said about the pursuit of happiness in life.) You may find that in business, your greatest profit results when you set aside financial yield in order to follow the dictates of respect, kindheartedness, or benevolence. This view was seen in the conduct of Merck \& Company, which gained recognition for its commitment to social responsibility during the 1980 s. The company made its drug for 'river 
Table 1 The moral and economic value of virtue

\begin{tabular}{|c|c|c|}
\hline Virtue & Moral value & Business value \\
\hline Civility & $\begin{array}{l}\text { Treating others with respect, courtesy and } \\
\text { politeness; due regard for respecting } \\
\text { cultural differences }\end{array}$ & $\begin{array}{l}\text { Success in business typically requires treating } \\
\text { people with courtesy and respect. After all, } \\
\text { customers and clients are free to take their } \\
\text { business someplace else. Also civility } \\
\text { increases the efficacy of communication }\end{array}$ \\
\hline Sympathy & $\begin{array}{l}\text { Capacity to understand the emotions } \\
\text { and feelings of other people }\end{array}$ & $\begin{array}{l}\text { Success requires understanding the needs of } \\
\text { customers as well as employees }\end{array}$ \\
\hline Justice & Inclination to act equitably & $\begin{array}{l}\text { Treating small matters fairly will engender } \\
\text { heightened degree of trust in business } \\
\text { relations over the long-run }\end{array}$ \\
\hline Gratitude & $\begin{array}{l}\text { Inclination to show appreciation for } \\
\text { assistance, benefits and gifts received from } \\
\text { others }\end{array}$ & $\begin{array}{l}\text { Shows that people are not capable of attaining } \\
\text { success only through their own efforts, but } \\
\text { require the assistance of others }\end{array}$ \\
\hline Trustworthiness & Disposition to be consistently dependable & $\begin{array}{l}\text { Removes necessity for excessive oversight of } \\
\text { contractual compliance, reducing agency } \\
\text { costs }\end{array}$ \\
\hline Honesty & Inclination to tell the truth & $\begin{array}{l}\text { Reduces occurrence of fraud and deception, } \\
\text { leading to greater degree of trust }\end{array}$ \\
\hline Temperance & $\begin{array}{l}\text { Self-discipline; tendency to avoid immediate } \\
\text { gratification for long-range achievement }\end{array}$ & $\begin{array}{l}\text { Engenders sustainable growth and } \\
\text { long-term stability }\end{array}$ \\
\hline Courage & $\begin{array}{l}\text { Disposition to assume appropriate level of } \\
\text { risk, avoiding rashness on the one hand, } \\
\text { and timidity on the other; elevation of } \\
\text { concern for common good over narrow } \\
\text { regard for self-preservation }\end{array}$ & $\begin{array}{l}\text { Inspires confidence and trust among others } \\
\text { in leadership ability }\end{array}$ \\
\hline Humility & $\begin{array}{l}\text { Tendency to be humble; not seeking } \\
\text { recognition or credit; willingness to admit } \\
\text { mistakes and assume blame }\end{array}$ & $\begin{array}{l}\text { Prevents expectations from becoming over } \\
\text { elevated. Inhibits being placed under the } \\
\text { spotlight so that when mistakes are made, } \\
\text { even trivial ones, one becomes vulnerable } \\
\text { to attack, thus threatening reputational } \\
\text { capital }\end{array}$ \\
\hline Friendliness & $\begin{array}{l}\text { Treating people equally with the thought of } \\
\text { good in mind; passing along your own } \\
\text { happiness to others }\end{array}$ & $\begin{array}{l}\text { Creates incentives for others to make initial } \\
\text { approaches, opening the door for entry into } \\
\text { transactions and establishes a willingness to } \\
\text { cooperate. }\end{array}$ \\
\hline Generosity & $\begin{array}{l}\text { Reaching the right balance between the } \\
\text { extremes of miserliness and prodigality }\end{array}$ & $\begin{array}{l}\text { The giving, philanthropically-minded busi- } \\
\text { nessperson or firm is seen as a genuine } \\
\text { leader, which inclines business partners to } \\
\text { extend their trust }\end{array}$ \\
\hline
\end{tabular}

blindness'-a parasitic infection common in tropical regions and afflicting 18 million individuals -available at no charge. In 1987, Merck shared its findings regarding treatment of human immunodeficiency virus (HIV) with its business competitors. The business justification for such efforts can be traced back to the philosophy of its founder, George W. Merck, who expressed his vision for the company as follows:

We try to remember that medicine is for the patient. We try never to forget that medicine is for the people. It is not for the profits. The profits follow, and if we have remembered that, they have never failed to appear. The better we have remembered it, the larger they have been (Merck 1950).

Reflecting on these sorts of concerns provides impetus for rejecting any extreme view about the place of profit-maximization in the free market. The fruits of the free market economy 
Table 2 Virtuosity in music and business

\begin{tabular}{|c|c|c|}
\hline Virtuosity-in-music & Virtuosity-in-business & Characteristics \\
\hline $\begin{array}{l}\text { Compositional: J.S. Bach engages } \\
\text { laws of harmony and } \\
\text { counterpoint within a particular } \\
\text { historical and doctrinal context } \\
\text { (Baroque era system of tonality) }\end{array}$ & $\begin{array}{l}\text { Entrepreneurial: envisioning a new } \\
\text { business model; a blueprint. Bill } \\
\text { Gates, Steve Jobs, Mohammed } \\
\text { Yunus (social entrepreneurship) }\end{array}$ & $\begin{array}{l}\text { Creativity, vision, confidence, } \\
\text { trend-setting }\end{array}$ \\
\hline $\begin{array}{l}\text { Improvisational: J.S. Bach, as a } \\
\text { master improvisator is able to } \\
\text { extemporaneously create complex } \\
\text { contrapuntal renditions. (Zen } \\
\text { Guitar: improvisation is strategic) }\end{array}$ & $\begin{array}{l}\text { Strategic: Sun Tzu's Art of War: the } \\
\text { battle is won before it is begun; } \\
\text { everything cannot be specified in } \\
\text { advance }\end{array}$ & $\begin{array}{l}\text { Resourcefulness, courage, } \\
\text { flexibility, adaptability, } \\
\text { preparedness }\end{array}$ \\
\hline $\begin{array}{l}\text { Performative: J.S. Bach is one of the } \\
\text { greatest organists of his time. } \\
\text { (Clementi vs. Mozart; Liszt vs. } \\
\text { others; Tchaikovsky and Chopin } \\
\text { piano competitions) }\end{array}$ & $\begin{array}{l}\text { Administrative skill: excellence in } \\
\text { putting a plan into action; being } \\
\text { detail-oriented and efficient; de- } \\
\text { livering results; evidenced in the } \\
\text { concept of "performance-based" } \\
\text { bonuses. }\end{array}$ & $\begin{array}{l}\text { Competitive instinct; "practice, } \\
\text { practice, practice;" ability to } \\
\text { learn from mistakes; greatly } \\
\text { exceeding technical mastery; } \\
\text { not simply mechanical but } \\
\text { artistic }\end{array}$ \\
\hline $\begin{array}{l}\text { Directive: J.S. Bach is director of the } \\
\text { Collegium Musicum }\end{array}$ & $\begin{array}{l}\text { Executive (leadership/managerial } \\
\text { skill) }\end{array}$ & $\begin{array}{l}\text { Helping others to be the best they } \\
\text { can be }\end{array}$ \\
\hline
\end{tabular}

${ }^{\text {a }}$ Bach assumed directorship of the Collegium in the spring of 1729. In the winter, the ensemble performed on Friday nights $(6 \mathrm{pm}$ to $8 \mathrm{pm})$ in Zimmermann's coffee house on the Catherine Strasse, located near the Marktplatz. During the warmer season, the music moved outdoors, to the coffee garden, with performances on Wednesdays (4 pm to $6 \mathrm{pm}$ ).

come about only within a framework of cultural norms and moral values, and when a steady eye on profitability is maintained, yet practically never held out as the primary motivation for doing business.

Aristotle held that happiness arises out of virtue. However, a virtuous person does not aim directly at happiness. Instead, one's motivation is to attain something else: honor, rectitude, nobility. For Aristotle, happiness does not arise from ephemeral feelings of pleasure experienced alike by self-centered and altruistic persons. Happiness is tied to an established state of satisfaction with who you are, your plight, and your relationship with others and the world. Human wellbeing is not situated in any particular set of experiences. Rather it inheres in the state within which one flourishes in line with one's nature, the way that a sunflower blossoms in the sun and a dolphin thrives in the open sea. In order to ensure that a child will be capable of exercising control over her life, to be assured in her choices, and to earn respect from others, we give her guidance in developing wisdom, temperance, courage, and a sense of justice. Such is the route towards human well-being. It is the same route as that towards enduring success in business.

Table 1 illustrates some ways various virtues contribute value in the business context.

As should be clear from the analysis given in this article, indicating that there is a connection between virtuous conduct and market benefits, does not mean that virtue should be taken to be something of instrumental value only. Virtue must first of all be valued for its own sake to maintain authenticity.

\section{Exemplars of Virtuosity}

In both music and business there is a reciprocal input-output relationship between cultural assets and the creative fruits that emerge from them. That is, cultural resources are initially 
drawn upon and then reproduced in return. On the one hand, it takes cultural backing, knowledge, institutions, and traditions to give rise to composers who can write beautiful music, performers who can give life to it, and teachers who can pass on our collective musical heritage. On the other hand, by creating and performing beautiful music, our common cultural resources are in turn replenished. When operating at its best, the same dynamic occurs in business. For instance, the existence of a talented, well-educated workforce assists companies in providing quality goods and services, and in being innovative.

It is instructive to consider commonalities between virtuosity-in-music and virtuosity-inbusiness. The comparison should not be too surprising. After all, music in many respects owes its existence to business (we speak of "the music business") and like music, business (at least considered in its most positive aspects) is sometimes capable of providing enrichment, bringing a sense of purpose and meaning, and importing beauty in people's lives.

Table 2 highlights common threads of human excellence in music and business. Distinguishing the various exemplars of virtuosity is not meant to suggest that these exemplars are isolated from one another in practice. To the contrary, these forms reinforce one another. And virtuoso businesspeople as well as virtuoso musicians often embody more than one or even all of them.

\section{Personifications of Virtuosity}

We need not strain too hard in linking virtuosity in music and business. History provides instances of individuals embodying twin gifts of musical genius and exemplary business acumen. Such cases abound, stretching from Haydn contemporary Johann Tost (an accomplished Hunagarian violinist as well as respected wholesale cloth merchant) up to jazz artist Kenny $\mathrm{G}$ of the present (who studied accounting at the University of Washington while performing his saxophone by night) (Block 2002, 30). Here the discussion will focus on two especially intriguing music-business masterminds: Clementi and Ives.

\section{Muzio Clementi}

Apart from his prominence as a composer and virtuoso pianist, Muzio Clementi was also a highly successful entrepreneur, a fact which may come as a surprise to many unfamiliar with the extent of his extramusical exploits. Born in 1752, four years before Mozart, Clementi began his musical career as a child prodigy, playing both harpsichord and the organ with great virtuosity. As a teenager, he practiced and experimented relentlessly, developing a bold and brilliant and technique, with a signature legato style. He played rapid octaves, and often composed passages in his signature style of thirds and sixths. Ignatz Moscheles, a conductor, composer and himself one of the greatest piano players in history, wrote:

Clementi's pianoforte playing, when he was young, was famed for the exquisite legato, pearliness of touch in rapid passages, and unerring certainty of execution.

Even now the remains of these qualities were recognized and admired, but what chiefly delighted his audience was the charm and freshness of his modulations in improvisation (Moscheles 2009, 87).

Clementi countered Mozart in a pianistic duel on December 24, 1781, in view of Viennese Emperor Joseph II and his guests. Clementi opened with an extemporaneous prelude, followed by his own Sonata in B-Flat Major (Op. 24, No. 2) and then a toccata showcasing his trademark 
double-notes. His contender Mozart followed with an improvised prelude and a sequence of variations. Music critic Harold Schonberg dramatically recounts what transpired next:

The Grand Duchess produced some sonatas of Paisiello ("wretchedly written out in his own hand," later complained Mozart), and both pianists read them off at sight, Mozart playing the allegros, Clementi the adagios and rondos. Both were asked to select a theme from one of these sonatas, developing it on two pianos. Presumably Mozart would have taken a theme and played it, Clementi noting the harmonies. Then Clementi would have accompanied Mozart on the second piano while Mozart developed his material. And vice versa. It probably ended with a grand two-piano splash, in which all the melodic fragments were woven together (Schonberg 2006, 52).

Clementi's technical skill turned out to be equal if not superior to that of his rival, who on the other hand infinitely surpassed him by the passionate beauty of his interpretation. The Emperor called the match a draw (Ewen 1937, 105).

After the event, Mozart intimated his impressions of Clementi's playing in a letter to his father: "He has great facility with his right hand. His star passages are thirds. Apart from that, he has not a farthing's worth of feeling; he is a mere mechanicus" (Schonberg 2006, 54). Clementi's impressions of Mozart, by contrast, were enthusiastic and filled with praise for Mozart's fine taste and singing touch (Id., 52). Later on, Clementi's student Ludwig Berger recalled: "Until then I had never heard anyone play with such spirit and grace. I was particularly overwhelmed by an adagio and by several of his extempore variations for which the Emperor had chosen the theme.. .." (Rosenblum 1991, 25).

The main theme of Clementi's Sonata in B-Flat Major, captured Mozart's imagination. Ten years later, in 1791, Mozart incorporated it in the overture to his opera Die Zauberflöte (The Magic Flute). This so embittered Clementi that every time this sonata was published, he made certain that it included a note explaining that it had been written ten years before Mozart began writing Zauberflöte. Clementi's admiration for Mozart, obviously not reciprocated, was reflected in a large number of transcriptions he made of Mozart's music, among which is a piano solo version of the "Zauberflöte" overture.

The business side of Clementi's life began to take root in England, where he entered the business of crafting pianofortes. First, he acquired shares in the pianoforte business of a firm that had gone bankrupt in 1800 , He then established a pianoforte and music business of his own; under the name Clementi \& Company. In the course of running this firm he dramatically improved the art of piano building.

Clementi was a music publisher as well, and brought to the public a stream of new publications, including much of his own music. As a piano teacher, Clementi produced important pianists, including John Field, composer of the famous Nocturnes, as well as Johann Baptist Cramer, a friend of Beethoven's who also became a successful music publisher and instrument manufacturer.

Clementi helped to establish respect for the musician and also for music teaching, a profession that at the time was considered neither respectable nor gentlemanly. Franz Joseph Haydn and other master musicians, for instance, were accorded a status not much higher than that of servants.

Clementi's enlarged view of piano technique was codified in his 1817 magnum opus, Gradus ad Parnassum, a set of one hundred pieces including etudes, slow movements, fugues, and canons. Clementi's pianism was still of the Classical period, but his work in many ways presaged what the piano would eventually be required to perform. 
Beethoven was deeply indebted to the Clementi sonatas and is said to have kept his volume of them always at hand. Brahms, too, admired Clementi's adventurousness and freedom of form. From the pianist view, Clementi's etudes formed the foundation for the future of etude writing, culminating in the Chopin etudes. It is worth noting that Chopin's pupils were not permitted to even come close to their teacher's own etudes unless they already had gained a solid grasp of Clementi's.

Clementi maintained extensive contacts with European publishers and instrument sellers, including Artaria, Breitkopf \& Härtel, Erard, Naderman, Nägeli, Pleyel, Ricordi and Streicher. Clementi was held in great esteem among musicians all over Europe, including Haydn, Dussek, Beethoven, Bomtempo, Himmel, Righini, and Nezot. He was adroit at making use of his reputation as a musician to strengthen his business dealings.

To summarize, Clementi was an intelligent and cultured person. Not only was he an energetic musician at the heart of the development of European musical institutions, he prospered as an extremely astute and well-respected businessman.

\section{Charles Ives}

With a reputation as one of America's most significant composers, of particular interest is the way Ives's music is far ahead of his time. Although conceived back the start of the twentieth century, his pieces already embody elements emerging decades later: polytonality, free atonality, pre-serialism, spatial music, music with microintervals, chance and collage effects, polyrhythm, polymeters, and polytempi. One of his most forward-looking works, the Universe Symphony, heralds "sound mass" composition, employed by György Ligeti and Krzysztof Penderecki in the 1950s and 1960s. In other ways, the symphony anticipates spectralist composition (which seeks a deep structure of sound embodied in its harmonic spectrum) of Tristan Murail and Edgard Varèse which emerged in the 1960s and 1970s.

By studying the various biographical portraits that have been rendered of Ives one can discern an underlying philosophy connecting Ives's musical vision and his career in business (Cowell and Cowell 1969; Burkholder 1996; Swafford 1996; Perlis 1976; Rossiter 1975; Feder 1999). This philosophy is based upon a quest for authenticity and integrity. It also flows from the pursuit of community and the values that sustain and enrich it.

Also strangely ahead of its time in the sense that it almost foreshadows some aspects of the financial scandals of recent vintage, was a wave of malfeasances in the insurance industry within which Ives was building his business career. Insurance profits were being channeled into various kinds of clandestine speculation, while the "big three" insurance firms (Mutual, Equitable, and New York Life) controlled many of their own banks and trusts. Consequently investors were led to unknowingly assume risks flowing from the insurance business.

In response to the rash of corruption and widespread abuses in the insurance industry, a committee established by New York's state legislator and chaired by Senator William Armstrong, targeted the nature and amount of compensation for insurance agents and agencies. In the wake of the investigation, New York State ended up adopting the strongest regulations in the United States.

There is no evidence implicating Ives himself in any illegal or unethical business conduct. However, since his work inside the insurance industry under scrutiny made him close enough to feel the heat, during the time surrounding the investigation Ives changed both artistically and personally. He suffered health complications. His business career nearly collapsed, and yet he 
steered it in innovative directions that enabled it to flourish in new and unanticipated ways. And his compositional style changed radically.

After a compositional hiatus in 1905, perhaps occasioned by anxieties arising from the Armstrong investigation, Ives devoted himself to writing exceptionally original and experimental works. Many of his pieces raise fundamental questions concerning the nature of music, while at the same time testing its stylistic and structural limits. And his philosophical questioning pervades many of these compositions.

For instance, Ives's The Unanswered Question probes a philosophical point similar to one raised by Rilke when the poet stressed the existential importance of learning to "love the questions" (Rilke 1986). In the background a whispering string chorale evokes, in Ives' terms, "the silence of the Druids." Piercing this muted backdrop a trumpet repeatedly states, in Ives' words, "the perennial question of existence." Responding to each question, a quartet of winds Ives dubbed the "fighting answerers" scrambles to put together a reply. Yet the ensemble turns increasingly agitated to the point of blurting out a seething and incoherent rant. At the end, the trumpet raises the question once more, answered by a hushed fade-out into silence.

Although while in the midst of the Congressional investigation Ives may have tried to escape into his inner world of musical creation, he was not able to avoid the business world he was immersed in, nor could he ignore the moral questions that accompanied it. He needed to come to grips with the insurance world from both philosophical and financial standpoints. As the Armstrong investigation unfolded, Ives could find an answer to at least the moral questions being raised. Thus, according to testimony given by Richard McCurdy, President of Mutual Life, although life insurance as practiced by mutual companies was actually a philanthropic and eleemosynary undertaking that served to benefit humanity at large, it was misunderstood as a crass and narrow moneymaking pursuit: "Every person ought to understand that when he takes a policy of life insurance that he is not doing it solely for his own benefit, but he is participating in a great movement for the benefit of humanity at large and for every other person who comes in and takes a policy in that company, and in that way joins the great brotherhood" (Broyles 141-42). According to Michael Broyles, that statement "is an almost exact statement of the beliefs that would guide Ives's work in the insurance industry and by extension become part of his overall philosophy" (Broyles 1996, 142).

In his personal life Ives was a religious believer, and he also kept faith in the redemptive capacity of art. He was ultimately seeking, he wrote, a "vision higher and deeper than art itself" (Ives 1970, 95-96). Ives believed that, according to an invisible law the human spirit evolves along with the rest of nature, toward perfection. This idea is prevalent both in his writing about his music and in business literature he produced as a practical guide to selling insurance. For instance, in a how-to sales publication The Amount to Carry - Measuring the Prospect, Ives writes:

There is an innate quality in human nature which gives man the power to sense the deeper causes, or at least to be conscious that there are organic and primal laws (or whatever you care to call the fundamental values of existence) underlying all progress. Especially this is so in the social, economic, and other essential relations between men (Ives 1920; Swafford 1996, 203).

We are all embarked upon a heroic personal voyage of growth and discovery that is part of the upward passage of all humanity. And music, Ives believed, plays an essential role in these expeditions. Whether music issues from a symphonic orchestra, a marching band, or a ragtime piano, the essence is the same, so long as it is earnest and authentic. External sound is the imperfect manifestation of the eternal inward spirit. "Music is life" (Swafford 1996, 238). 
Much of Ives's vision remains prescient and vital. Especially in a time when many seem to resist the idea that music, not to mention business, ought to have depth and substance, it's worth recalling how much Ives believed in the moral and spiritual importance of both endeavors. As Ives scholar Jan. Swafford notes, "[i]t is no accident that his phrase "human life values' means at once the cash value of a person's life and labor, and the humanistic and spiritual values people live by" (Swafford 1996, 209).

A founding partner of Ives and Myrick, the preeminent insurance agency of its time, he was not a conventional boss. His employees recalled Ives as an unforgettable figure who, in a shy and retiring way, was able to galvanize them with his ideals. "When [Ives] talked with someone," recollected one employee, "he elevated them.... It's very hard to describe, but he made everyone feel important." He taught his employees that "There was not a service that I could render to my fellow man that was more important than the business of life insurance, because it instilled in the soul and mind of my fellow man the responsibility of meeting his obligations" (Perlis 1976, 56).

To Ives, community originates with family and expands outward to towns, countries, the insured, the globe, the universe. Business was the fount of many of his artistic and spiritual ideals. As he studied actuarial science, which entails calculating risks and generating premium schedules that predict mortality probabilities over the long run, he was prompted to view human life in large terms, from the vantage point of masses of people progressing from birth to death (Swafford 1996, 209). Ives left the Mutual Insurance Company in 1906 to form his own insurance firm, Ives and Company, which three years later became Ives and Myrick. The company prospered, growing into one of the largest agencies of its kind. As senior partner, Ives was proud of his business success, feeling that experience contributed something important to the music he was composing - and vice versa. Here is how Ives expressed it, in terms that vividly encapsulate a number of insights explored in this article:

My business experience revealed life to me in many aspects that I might otherwise have missed. In it one sees tragedy, nobility, meanness, high aims, low aims, brave hopes, faint hopes, great ideals, no ideals, and one is able to watch these work inevitable destiny. And it has seemed to me that the finer sides of these traits were not only in the majority but in the ascendancy. I have seen men fight honorably and to a finish, solely for a matter of conviction or a principle - and where expediency, probably loss of business, prestige, or position had no part and threats no effect. It is my impression that there is more open-mindedness and willingness to examine carefully the premises underlying a new or unfamiliar thing, in the world of business than in the world of music.

It is not even uncommon in business intercourse to sense a reflection of a philosophy ... akin to a strong sense of beauty in art. To assume that business is a material process, and only that, is to undervalue the average mind and heart. To an insurance man there is an "average man" and he is humanity.

I have experienced a great fullness of life in business. The fabric of existence weaves itself whole. You cannot set an art off in the corner and hope for it to have vitality, reality and substance. There can be nothing exclusive about a substantial art. It comes directly out of the heart of experience of life and thinking about life and living life. My work in music helped my business and work in business helped my music (Cowell and Cowell 1969, 96-97). 


\section{Conclusion}

Business ethics can play a role in providing a broader, deeper, and more systematic account of business than many traditional discussions allow. It is in light of an imperative of nobility in business that the notion of virtuosity provides, or ought to provide, both a source of vision and a standard of excellence for market participants, whether they be individuals, or organizations, operating locally or globally.

The virtuoso businessperson, no less than the virtuoso musical artist, is one who loves excellence and pursues it passionately. She will seek to become properly trained, not just technically but in accord with deeper intellectual and professional promptings. Such an individual will make up her own mind, in authentic freedom, concerning the kind of moral environment in which she and her firm will move.

Virtues are dispositions that assist one in assuming risks, in making judgments, in taking ownership of one's conduct, and to recognize and appreciate sage counsel. The moral virtues constitute a vital portion of our ethical capital. However, drawing upon this stock of moralcultural resources is not something one can accomplish entirely from one's own effort and initiative, since it is rooted in our shared cultural legacy. As well, since we are social animals, we can achieve virtue and its attendant well-being only by playing our social roles well.

This article has argued that many of the qualities underlying musical virtuosity also underwrite virtuosity in business. Remaining mindful of the aspects in which musical and business performances remain dissimilar should not deter us from reflecting on profound points of similarity. One of the chief reasons for undertaking this comparison is that it helps us to envision business and businesspeople in a new light, something sorely needed in these times of profound disillusionment with economic institutions and economic actors. It would be a stretch to suggest that mundane aspects of doing business, say, running a convenience store are tantamount to delivering an aria at the Met. To think this way, however, is to miss the point, and those too quick to dismiss the value of positing a virtuoso metaphor for economic life, perhaps deeming business to be utterly irredeemable, pass up an opportunity for gaining deeper insight into what business might be if we changed our thinking about it and began to see it as a human endeavor ordained to the common good instead of as the ruthless profitmaximizing war of all against all it is often taken to be.

Putting doubts of detractors aside, what points of comparison can one make between the art of music and the art of business? It has been argued that in both instances one discerns a pursuit of excellence in the face of fierce competition, the need for discipline, the selfgoverning spirit, the heavy dependence on reputation. Qualities such as these are characteristic of successful musical flourishing (indeed, enduring artistic achievement in general), and are intricately woven throughout the business world as well. These are the components of virtuosity. Turning attention to these human-centered features promises to provide a fresh dose of inspiration that, given the pervasive unease about business within contemporary culture, we cannot afford to pass up.

A consequence of such an analysis is a bold conception of rational and free businesspersons as creative artisans. However, rather than painting an idealistic, Quixote-like portrait, this article has sought to come to terms with practical implications of taking virtue seriously in the hard-nosed world of competitive business - an environment which often threatens to "crowd out" virtues. Just how far can the metaphor of artistic excellence take us in a field where the relentless pursuit of profits seems to be the order of the day? Some business ethicists, particularly Kantians, are perplexed by any assertion that a businessperson or firm can choose 
something both for its own sake and for the sake of something else. Can a businessperson or company authentically choose to conduct an honest transaction for its own sake - because it's the right thing to do - yet also for the sake of boosting it reputation with clients, and consequently enhancing its profitability both in the near term and down the road? It is posited that choosing a virtuous action for its own sake and for the sake of other ends makes sense taken at face value, given that the pursuit of those further ends does not undermine the choice of the virtuous act undertaken in the first place. The plausibility of this account is maintained once we place profitability in proper perspective. That is, one recognizes that for the virtuous businessperson or firm, profitability, albeit an important goal, is not the narrow sine qua non of all business activity that some extremists tout it to be. Instead, profitability is a reasonably predictable result flowing from the pursuit of virtuosity: excellence in providing a valuable good or service for the common good.

Virtuosity, then, is not simply about exhorting business actors to display excellence in "doing the right thing." When considered in a managerial context of a market economy, virtuosity is equally connected with performance, competition, success and the creation of value for oneself and others. For this reason, this article has posited the model of musical virtuosity as an analogical archetype for deepening our understanding of, and quest for cultivating, virtue-in-business. Admittedly, a conception of virtuosity in business is, in a sense quite idealistic. However it is from such an outlook that business can be seen, as it was to the visionary composer and insurance executive Charles Ives, as a noble activity.

\section{References}

Bintliff, E. (2007). Grand theft piano, Newsweek, 28 May, 60-62.

Block D.G. (2002). Kenny G plays on the soundtrack of people's lives. Billboard, 14 September, 30.

Broyles, M. (1996). Charles Ives and the American democratic tradition, in Charles Ives and his world, J. Peter Burkholder, ed.

Burkholder, J.P. ed. (1996). Charles Ives and his world.

Chinchilla, N. and Moragas, M. (2008). Masters of our Destiny.

Chopra, D. (1994). The seven spiritual laws of success.

Clark, E. (2010). Goldman Sachs and legality vs. morality, The CSR Blog, Forbes.com.

Collins, J.C. and Porras, J.I. (1994). Built to last: successful habits of visionary companies.

Coster, H. (2009). The biggest ceo outrages of 2009: this year's c-suite hall of shame, Forbes.com.

Cowell, H. and Cowell, S. (1969). Charles Ives and his music.

Ewen, D. (1937). Composers of yesterday.

Feder, S. (1999). The life of Charles Ives.

Ives, C. (1920). The amount to carry - measuring the Prospect, Ives \& Myrick Publication, Salesmanship Ed.

Ives, C. (1970). Essays before a sonata and other writings, Howard Boatright, ed., 95-96.

Jackson, K. 2004. Building reputational capital. New York: Oxford University Press.

Jackson, K. (2010). The scandal beneath the crisis. Harvard Jounal of Law and Public Policy.

MacIntyre, A. (1984). After virtue: a study in moral theory. Univeristy of Notre Dame Press.

Merck, G.W. (1950). Speech at the Medical College of Virginia at Richmond, 1 December 1, at 48, quoted in Collins, J.C. and Porras, J.I. (1994). Built to last: Successful habits of visionary companies.

Moscheles, C. (2009). Recent music and musicians; As Described in the Diaries and Correspondence of Ignatz Moscheles.

Paine, L. and Mavrinac, S. (2009). AES honeycomb (a), (B), Harvard Business School Case.

Paine, L. and Wruck, K. (2005). Sealed air corporation: globalization and corporate culture (a), (B), Harvard Business School Case.

Paine, L., Knoop, C. and Raju, S. (2001). HDFC (A), (B), Harvard Business School Case.

Perlis, V. (1976). Charles Ives remembered: An oral history.

Rilke, R.M. (1986). Letters to a young poet, S. Mitchell, trans.

Rosenblum, S.P. (1991). Performance practices in classic piano music: their principles and applications. 
Rossiter, F.R. (1975). Charles Ives and his America.

Sartre. 1992/1943. Being and nothingness: a phenomenological essay on ontology. New York: Washington Square Press.

Schonberg, H.C. (2006). The great pianists.

Smith, A. (1759). The theory of moral sentiments.

Swafford, J. (1996). Charles Ives: a life with music.

Wakin, D.J. (2006). After La Scala boos, a tenor boos back. New York Times. 